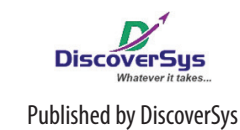

Published by DiscoverSys

\section{Tantangan dalam upaya penemuan anak usia di bawah usia lima tahun dengan gizi buruk}

\author{
Dewa Nyoman Wirawan ${ }^{1,2^{*}}$
}

mendatangi posyandu. Fenomena seperti ini kemungkinan tidak hanya terjadi di Bali, tetapi juga di daerah lainnya di Indonesia. Bila cakupan penemuan balita gizi buruk dan sangat kurus tidak cukup tinggi dan segera bisa ditangani maka hal ini akan mempersulit target MDGs untuk menurunkan angka kematian bayi dan balita. Selain itu, kondisi ini akan menyebabkan kemiskinan turun temurun karena asupan gizi yang kurang akan mempengaruhi kecerdasan anak sehingga mereka tidak akan mampu melanjutkan pendidikannya pada tingkat yang lebih tinggi, dan setelah dewasa tidak mampu untuk mendapatkan kesempatan kerja yang lebih baik, sehingga orang tuanya yang saat ini dalam keadaan miskin akan dilanjutkan oleh anaknya yang juga akan tetap miskin.

Satu-satunya jalan keluar untuk mengatasi tantangan ini adalah mencari secara aktif dari rumah ke rumah dan difokuskan pada rumahtangga miskin yang datanya saat ini telah tersedia di seluruh Indonesia dalam data base Program Perlindungan Sosial 2011. Dengan duduk bersama, kesulitan pendanaan dalam memberikan insentif kepada kader untuk menjalankan tugas kunjungan dari rumah ke rumah pasti bisa dicarikan jalan keluarnya.

\section{DAFTAR PUSTAKA}

1. Bappenas (2010). Peta Jalan Percepatan Pencapaian Tujuan Pembangunan Milenium di Indonesia.

2. Bappeda Provinsi Bali (2011). Rencana Aksi Daerah Tujuan Pembangunan Milenium Provinsi Bali.

3. Badan Penelitian dan Pengembangan Kesehatan Departemen Kesehatan RI (2010). Laporan Nasional Riset Kesehatan Dasar (Riskesdas) Tahun 2010.

4. Badan Pusat Statistik Provinsi Bali (2011). Menuju Era Baru Kependudukan Provinsi Bali, Analisis Profil Kependudukan Provinsi Bali (Hasil SP2010).

5. Dinas Kesehatan Provinsi Bali (2013). Profil Kesehatan Provinsi Bali Tahun 2012.

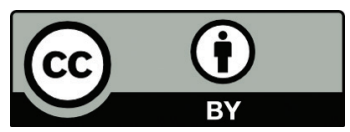

This work is licensed under a Creative Commons Attribution
*Korespondensi penulis: Dewa Nyoman Wirawan, Program Studi Magister IImu Kesehatan Masyarakat Universitas Udayana, Bagian IImu Kedokteran Komunitas dan Ilmu Kedokteran Pencegahan Fakultas Kedokteran Universitas Udayana

wirawandewa48@gmail.com kader posyandu dan petugas puskesmas amat terbatas karena kebanyakan anak balita gizi buruk dan sangat kurus berada pada rumahtangga miskin dan mereka kebanyakan bertempat tinggal agak jauh serta terpencil dari lokasi posyandu; 2) keluarga miskin kebanyakan berpendidikan rendah dan akses mereka pada informasi juga amat minimal sehingga mereka tidak secara aktif 